\title{
THE WAY TO OVERCOME STUDENTS' HESITATION IN SPEAKING ENGLISH AT THE10TH GRADE OF SENIOR HIGH SCHOOL IN BEKASI
}

\author{
Grediana Rumlus
}

English department, Academy of Foreign Language, Cipto Hadi Pranoto

Email: gredirumlus@gmail.com

\section{Artikel info}

Artikel history:

Received : 07-09-2020

Revised : 15-09-2020

Approved : 20-09-2020

Keywords: Habit, watching/listening, fun
Abstract: English as an international language needs to be used in daily communication so that speakers are accustomed to using it. But the facts show that many people, especially class X students at one of the high schools in Bekasi, find it difficult to speak English for fear of being wrong. So this paper aims to find out the causes of difficulties for students to speak English. The author conducted research in 2 classes with 60 students. The first step is to hold a group discussion using an English textbook in the two classes. The second stage uses the control class and the experimental class. The control class still uses English textbooks as discussion material, while the control class watches 2 films in English and each group tells the contents of the film according to their understanding. Each group member in the experimental class tells the contents of the film very actively and enthusiastically, while the control class only talk by the group leader. The observations showed that audiovisual and learning techniques with stories were very significant in the experimental class students. It can be proven by the activity of each group member speaking. It was concluded that audiovisual and simple learning techniques were very enjoyable and increased the speaking activity in one of high school students at grade X in Bekasi.

Correspondence author: Grediana Rumlus

Email: gredirumlus@gmail.com open access articles under license

CC BY SA

2020

\section{INTRODUCTION}

English as an international language is always used in daily activities, especially in business. But English is still a scary subject for students in elementary school to high school level. Or in other words English is difficult to use in formal education or in everyday life.

According to M.F Patel and Praveen (2008:6) "English is the international language. English is the concept of the English language as a global means of communication in numerous dialects, and also the movement towards an international standard for the language. It is spoken all over the world". It is known that many countries use English to communicate each other. Therefore, people considered that English is very important.

Language can be applied in speaking and writing. According to Richard (2002:111) "Languages should be a bridge between people but sometimes it can be a barrier". So without language, people cannot communicate among one another.

In this case, English as one of important language, it has been put as compulsary subjects at school. It means that students learnt English to be used in their daily life. One of the important things in learning English is vocabulary. 
The Way to Overcome Students' Hesitation in Speaking English at The10th Grade of Senior High School in Bekasi

In general, students have difficulty when they have to use English to explain something or just talk simple things with their classmates. In fact, if observed around them many people do not undergo formal education but these people easily communicate with foreign tourists. Examples include street vendors, masseurs or tattooists on the beach in Bali. There are several factors that cause students and even adults to be afraid of speaking English.

1. Less vocabulary. When students want to speak, they are hesitate because it is difficult to find the right words in developing sentences that will be used to speak in English. In other words they feel they don't have the word differences.

2. Grammar. Students are very careful in using sentences because they focus on how to use correct and standard English grammar. Yet it must be realized that when speaking grammar it should be ignored so as not to influence the speaker in speaking to build self-confidence.

3. Environmental factors. The influence of environmental conditions that do not speak English is a psychological obstacle for students to be reluctant and even ashamed to speak English even with simple sentences.

4. Fear of being ridiculed.

Feeling ashamed and afraid of being ridiculed is a burden that cannot be overcome by students or people who want to speak English. Why? Because when someone speaks a foreign language then by itself the person is considered arrogant or wants to show his expertise in front of others, plus if the person might make mistakes in pronunciation or intonation it will be a laughing stock of his listeners.

\section{METHOD}

To overcome the main problem "why don't students dare to speak English?" Even though students speak in simple sentences. Based on this problem, it is necessary to have a speaking technique that is simpler and more fun. The steps used are learning and applying vocabulary in simple sentences so that students begin to get used to and enjoy a pleasant learning atmosphere.

In interpreting this way of learning, the writer uses the audiolingual method and learning technique by Penny Ur in the book "(Ur, 1996)", the book provides the following learning techniques

1. Base activity on easy language

2. Make a careful choice of topic and task to stimulate interest

3. Give some interesting training in discussing skills

4. Keep the student speaking the target language

5. Use group of work, role play, simulation and debate.

After observing and learning the techniques above, the writer tries to apply some simple steps in the classroom learning proses as follows:

1. Carry out a "chain message game"

2. Showing an interesting film footage.

3. Together with the students see the topic in the film.

4. Arrange simple sentences based on the topic

5. students form groups of 3 people.

6. Each group reads the sentences over and over again, then each group starts implementing a chain message by conveying each sentence quickly and correctly.

7. Each group with the best performance is given a reward point in the form of group score. 


\section{RESULT AND DISCUSSION}

Based on the research, the causes of students not daring to speak English, things are sought that can overcome these obstacles. There are several steps that can be used to inspire students or speakers to comfortably speak English boldly as follows:

1. Require the classroom and school environment to speak English on certain days and hours according to mutual agreement.

2. Conduct audiovisual classes by watching movies together in class or in the school hall.

3. Hold an English debate, speech and story telling competition.

4. Students are given the task of discussing a hot topic on an English-based media.

5. Give rewards to students or group of students who are actively foster English school clubs and directly involve inviting fellow students to speak English in the classroom or school environment.

Furthermore, after conducting several experiments on 2 classes namely class X. Class A has 30 students and class B consists of 30 students. class A is made into the experimental class and class B is the control class. How to implement both classes undergo Pre-learning in which students in grup reads and disscuss a topic from an English textbook and then try to submit their conclusion. Only 8 students from the two classes were able to draw conclusions in English well. Then the experimental class and the control class were held. In this stage the control class continued to follow the group learning process by discussing material from English textbook while the experimental class was divided into 9 groups consisting of 3 students. The whole group watched two films from A star is born and Skate Kitchen. Then, each group immediately makes a conclusion and presents alternately according to their version. Time is limited for each group so they must race to deliver smoothly and straightforwardly. The results of each group are quite competitive because the versions submitted are very varied and inspiring. From the point of view of speaking, almost every active group member gave an opinion about the material they were conveying. From the results of each group's presentation it can be seen that the audiovisual way is very helpful for students to be active in speaking, even quiet students can interact well in their groups.

In preparing English subject matter especially speaking sessions, an English teacher certainly has his own way to get students actively involved in speaking. The teacher has given a rule of the game. These rules are made a habit in the classroom. Beginning when starting lessons each student takes turns in each lesson. One of the students stand up in front of the classroom and lead all students to start praying in English then greet the teacher. Furthermore, the teacher as an example began to interact with students by speaking English. Reviewing the previous lesson, inviting students to be actively involved by giving questions related to student circumstances. Entering the core material, the teacher explains an interesting topic, related to the subject matter. The next step is to discuss the topic in groups, sometimes the discussion is taken from the movies they are watching in the classroom. Then the teacher divides students into groups, each group must have a student who has an average skill above the other group members. The goal is for the student to become the group leader as well as a motivator to engage other students in speaking interactions. The teacher gives a time limit, then asks each group to share the results of their discussion in turn. Before class ends, the teacher gives a conclusion and scores to each group.

\section{CONCLUSION}

Based on the discussion and circumstances found in the implementation of the teaching process how to invite students to be actively involved and dare to speak simple sentences in class. The teacher Always preceded by a habit, a speaking habit will make students directly 
The Way to Overcome Students' Hesitation in Speaking English at The10th Grade of Senior High School in Bekasi

be able to express a sentence easily without being burdened. This can be proven through their habit of speaking English prayers every morning. Every student is without exception able to speak fluently and confidently. Furthermore, by the way teachers often interact with students in English when reviewing lessons, students are expected to often hear these unusual sentences and encourage them to respond to every question in English. Then when entering the core lessons, students are asked to listen, see, examine and discuss with their friends in a relaxed but directed atmosphere and given the responsibility to present conclusions with their version. After going through the learning process by inviting students to learn actively it can be concluded that audiovisual and discussion techniques can help students speak English actively and confidently. 
The Way to Overcome Students' Hesitation in Speaking English at The10th Grade of Senior High School in Bekasi

\section{Bibliografi}

A Course in Language Teaching by Penny UrBasic English by Julie Lachance

The ESL/ELL Teacher's guide by Larry Ferlazzo and Katty Hull Sypnieski Mengembangkan Media Pembelajaran Interaktif. Oleh Sri Huning Anwariningsih 2016

The Way To Overcome Students' Hesitation In Speaking English At The 10th Grade Of Senior High School In Bekasi 